\title{
Innovation embedded in entrepreneurs' networks and national educational systems
}

\author{
Thomas Schott $\cdot$ Mahdokht Sedaghat
}

Accepted: 9 December 2013/Published online: 28 February 2014

(C) The Author(s) 2014. This article is published with open access at Springerlink.com

\begin{abstract}
The proposition that entrepreneurs' innovation is embedded in networking is refined. We distinguish between networking in the public sphere and networking in the private sphere, and hypothesize that innovation benefits from public sphere networking but suffers from private sphere networking. These hypotheses are tested with a representative sample of 56,611 entrepreneurs in 61 countries surveyed in the Global Entrepreneurship Monitor. Hierarchical linear modeling shows that, while overall networking benefits innovation, innovation is decreased by private sphere networking and increased by networking in the public sphere, especially in the professions and internationally. A further refinement is to consider entrepreneurs' endeavors as embedded in society with its system of education for entrepreneurship. We hypothesize that the quality of a national system moderates the impacts of networks on innovation by adding value to networks. Analyses show that quality of national educational system adds innovation benefits to both public sphere networking and private sphere networking.
\end{abstract}

Keywords Entrepreneurs - Innovation · Networks · Social capital · Private sphere · Public sphere

T. Schott $(\bowtie) \cdot$ M. Sedaghat

Department of Entrepreneurship and Relationship Management, University of Southern Denmark, Kolding, Denmark

e-mail: tsc@sam.sdu.dk
JEL Classifications $\quad \mathrm{C} 210 \cdot \mathrm{I} 25 \cdot \mathrm{L} 26 \cdot \mathrm{L} 140$.

$\mathrm{M} 130 \cdot \mathrm{O} 31 \cdot \mathrm{Z} 130$

\section{Introduction: innovation embedded in networks and society}

Entrepreneurial activity denotes perception and pursuit of opportunities. This activity is usually considered the work of individuals, entrepreneurs. An entrepreneur may see an opportunity, mobilize and acquire resources, create a competitive advantage compared to other entrepreneurs, and exploit the opportunity, especially by being innovative (Shane 2003). This entrepreneurial process may be purposive rational action, following a business plan with evaluation of ideas and markets and with a calculation of costs and utility, or the process may be more of an effectuation of circumstances with an assembly of available resources (Sarasvathy 2008). This echoes a recent review with a conceptualization, Entrepreneurship...is carried out by individuals, entrepreneurs,... [who] perceive and create new opportunities...The entrepreneurial activity and the entrepreneurial ventures are influenced by the socioeconomic environment... (Carlsson et al. 2013, p. 914; italics in original). The influence by the socioeconomic environment will here be conceptualized as embeddedness in networks at the micro-level and in social institutions at the macro-level. 


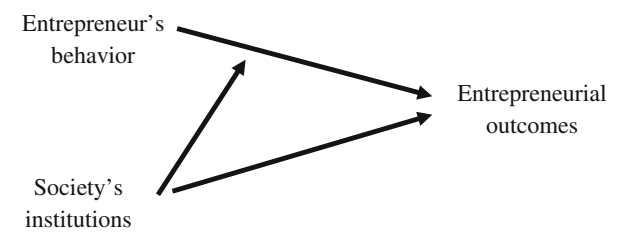

Fig. 1 Individual and societal effects on entrepreneurial outcomes

In the entrepreneurial process, the entrepreneur is not acting alone but together with others, and thereby the entrepreneurial activity is embedded in the network around the entrepreneur (Granovetter 1985). The entrepreneur networks with others who may provide advice and other resources for the business. The network may include an entrepreneurial group, a team of founders, or the family as in a family business. The entrepreneur's networking is a social capital, an investment in relations that may benefit performance, e.g., innovation.

Individual behavior in the entrepreneurial process - such as networking and innovating — is further embedded in society. Society comprises a configuration of social institutions, e.g., the educational system, which provides a framework that is more or less favorable for entrepreneurship. Thereby society affects entry and other inputs into entrepreneurship, affects the entrepreneurial process, and also affects outcomes by impacting outcomes and moderating the process by which individual behavior leads to outcomes (Fig. 1).

This conceptualization of entrepreneurial activity has the theoretical advantage of combining the microlevel focus on individual behavior with the macrolevel focus on societal framework conditions. Moreover, our modeling shall estimate effects on entrepreneurial outcomes from both the individual and societal level, both direct and less direct effects. Our study focuses on an entrepreneurial outcome, innovation, as it is shaped by an individual behavior, networking, and also by a social institution, the national system of education for entrepreneurship.

The recent review specifies, "Future research questions of interest include, for example, what are the types of interaction between entrepreneurs and other actors and between entrepreneurial activity and institutions/norms/laws that yield fruitful outcomes?" (Carlsson et al. 2013, p. 926). The interaction between entrepreneurs and other actors is here understood as networking, the interaction between entrepreneurial activity and institutions is here conceptualized as embeddedness in institutions in society, and here the fruitful outcome is innovation.

The review also points out that, "The systematic gathering of longitudinal internationally comparable data on multiple levels, such as that by the Global Entrepreneurship Monitor (GEM), should open up new avenues of research" (Carlsson et al. 2013, p. 927). The GEM data from around the world on the micro-level behavior of entrepreneurs and on the macro-level institutions are uniquely suited for our research on entrepreneurs' networking and innovation in the context of society.

The value of this study is that it is the first globally generalizable account of how innovation is embedded in various networks around entrepreneurs and also embedded in society. First, we review prior research, then specify hypotheses, describe our design and data, test our hypotheses, and in the conclusion also point to future research.

\section{Prior research}

Innovation differs among societies. Innovation surged in the societies in Northwestern Europe in the seventeenth century. This surge can be explained by a cultural value, the ethic promulgated by the new religion of Protestantism (Weber 1920). The ethic held it to be good to understand Nature, as the creation of God, as a way of getting closer to God, which was considered good, and even to transform Nature, and create innovations for personal gain and for the benefit of humankind. As envisioned and advocated by Francis Bacon in "New Atlantis," society institutionalized the social role of the innovator by providing legitimacy, motivation, organizations, facilities, and recognition for innovative endeavors, and the innovative persons considered their discoveries a celebration of God as God's work is expressed in Nature (Merton 1938).

Innovation in society may thus be enhanced by some cultural values and hampered by some other cultural values. The cultural value of individualism seems to promote innovation in society; innovation is higher in individualistic societies than in collectivistic societies (Shane 1992). The cultural value of masculinity, emphasizing achievement and performance and 
deemphasizing social and nurturing values (Hofstede et al. 2010), also seems to enhance innovation in society; innovation is higher in masculine societies than in feminine societies (Shane 1993). Conversely, the cultural value of uncertainty-avoidance (Hofstede et al. 2010) seems to hamper innovation; innovation is lower where uncertainty-avoidance pervades culture than where uncertainty is accepted in the society (Shane 1993). Power-distance (Hofstede et al. 2010), as the powerless people's acceptance of inequality of power, also seems to reduce innovation in society; hierarchical societies are less innovative than societies without a steep social hierarchy (Shane 1993; Weber 1920). Also trust in society may enhance innovation in the way that where trust pervades the culture, entrepreneurs will communicate more and their intensity of communication will promote their creativity and innovation (Shane 1992). The mechanism is that such cultural values in society motivate and enable people to innovate so as to increase the national rate of innovation.

Innovation has been secularized and globalized with a faith in innovation as a key to human progress toward a salvation of humankind, now theorized by a global regime led by UNESCO, UNIDO, OECD, the World Bank, and the World Economic Forum, which through an army of expert advisors provides governments with prescriptions for the pursuit of innovation (e.g., OECD 2010). Researchers-including the senior author of this study - are frequently called upon to join, support, theorize, and evaluate this global endeavor.

Countries are now also ranked according to their innovation, most prominently in The Global Innovation Index 2012: Stronger Innovation Linkages for Economic Growth (Dutta 2012). Innovation of a society is measured as an index combining knowledge (creation, diffusion, and impact) and creative outputs (creative intangibles and creative goods and services). Accordingly, the most innovative economies are Switzerland, Sweden, Singapore, Finland, the UK, The Netherlands, Denmark, Hong Kong, Ireland, and the US, and they are far more innovative than the least innovative societies, Sudan, Niger, Yemen, Lao People's Democratic Republic, Burundi, Togo, Angola, Côte d'Ivoire, Pakistan, Syria, and Ethiopia (Dutta 2012, xviii-xix). Innovation is considered a result of conditions and inputs such as institutions (political environment, regulatory environment, and business environment), human capital and research (education, tertiary education and R \& D), infrastructure (ICT, energy and general infrastructure), market sophistication (credit, investment, trade and competition), and business sophistication (knowledge workers, innovation linkages, and knowledge absorption). An index averaging these input conditions and the index of innovation output correlate highly (as the correlation is computed across the 141 indexed countries).

Innovation is considered as carried out in a national system where inputs lead to outputs. An important input in the national system is human capital, as indicated by the rate of education, rate of tertiary education, and rate of knowledge workers in the country. Another important input in the national system is social capital, as indicated by knowledge absorption and innovation linkages, as emphasized by the subtitle of the recent global index report reviewed above. The use of human and social capital is elaborated in the conception of the national system of innovation as a system of interactive learning (Lundvall 1992). Interactive learning and other flow of knowledge among participants are also fundamental to formation of a regional system of innovation and formation of a cluster in which the flow of knowledge becomes stimulated, intensified, and coordinated (Baptista and Swann 1998). Therefore, a component in the system of innovation is the knowledge institutions. Innovation was previously thought to flow rather linearly from knowledge institutions, but is now increasingly considered to be a task for entrepreneurial bridging and networking (Moulaert and Nussbaumer 2005).

Throughout the world, increasingly the focus is on education and training for entrepreneurship as such specialized instruction may be provided in society (Greene and Rice 2007). This specialized instruction is considered the principal policy means for longterm promotion of entrepreneurship and is expanding around the world. Apart from their formal and regular schooling for degrees, pupils receive entrepreneurship training during their schooling, and people receive entrepreneurship training upon graduation. In the population, training tends to make people more interested in starting a business, more competent to start a business, more perceptive of business-opportunities, and more risk-willing, and makes the population more favorable toward entrepreneurship (Coduras et al. 2010). The quality of education and training in 
society makes people more motivated and able to recognize and pursue opportunities and enter into entrepreneurship (Levie and Autio 2008). The national system of education and training raises human capital and also raises social capital by promoting knowledge flows in the national system of innovation.

The macro-level proposition that interactive learning and knowledge flow in the system benefits innovation of the system translates into the microlevel proposition that an entrepreneur or firm through networking can promote own innovativeness. The entrepreneur or firm may pursue innovation as an own endeavor and may network for absorbing knowledge or may pursue innovation in collaboration with others and thus move the locus of innovation into the network (Powell et al. 1996). The national system of education and training promotes networking; educated entrepreneurs network more than less educated entrepreneurs and trained entrepreneurs network more than entrepreneurs without entrepreneurial training, at least in Denmark and some other countries (Coduras et al. 2010, Chap. 6; Schott 2009, Chap. 7; 2010, Chap. 13).

A person's networking is social capital in that investing in relations is a way to mobilize and acquire resources that can bring benefits, so persons with much social capital accomplish more and achieve competitive advantages compared to persons with less social capital. The social capital may be in the form of information channels, in the form of expectations and obligations, or in the form of social norms. These forms of social capital are often intertwined, as when acquisition of information is embedded in an obliging family relation or embedded in a purchase of consultation with a professional who is expected to be trustworthy, according to a social norm (Coleman 1990).

Entrepreneurs can, through their relationships with others, build credibility, gain advice, seek financing, access customer, acquire information, and thereby enhance innovation (Dahl and Pedersen 2005; Edquist et al. 2000; Zhao and Aram 1995). Entrepreneurs often expand their networks to get information and other resources from others (Greve and Salaff 2003). Entrepreneurs' extent of collaborative relations correlates positively with their innovation (Pittaway et al. 2004). In earlier studies, social capital has mostly been operationalized as the size of the network around the person, the number of others or different kinds of others who are connected with the person. Since earlier studies have been small, local, and specialized, without much generalizability, it is appropriate to here retest the proposition with our global and fairly representative sample.

This proposition is a starting point for more nuanced considerations leading to refinements. First, the effect is unlikely to be linear and additive, in the way that if I have only few relations then one more relation will be important, but if I already have many relations then one more relation will be less important, so there is likely to be a declining marginal utility of relations (Kolvereid et al. 2009). Second, the more relations I have to maintain, the less energy I can invest in each relation, and the less I benefit from each relation, so if I pursue some relations intensely, the less my other relations will benefit me. Third, relations may have specific benefits rather than being generally useful; my relations with my family can support my emotional well-being, but cannot support me in my deliberations over teaching. Fourth, weak and bridging ties may be most beneficial for exploration, while strong and bonding ties may be more beneficial for exploitation of opportunities (Belussi et al. 2010; Davidsson and Honig 2003). Fifth, there may be redundancy among relations in the way that having one specific relation may make other relations rather redundant, especially to contacts possessing similar resources, as when my dealing with one bank makes it inefficient for me to also deal with a second bank (Gronum et al. 2012). Sixth, some relations may even be detrimental, as when my relations with my family reduce my risk-willingness to nil. Seventh, existence of relations between contacts may be beneficial in the way that closure between my contacts enables them to organize and coordinate support for me (Coleman 1990). Eighth, and contrary to closure, absence of relations between contacts may be beneficial in the way that holes between my contacts enable me to act with lesser constraint from them and to utilize more varied information channels; specifically, I may be an entrepreneur in the Latin or French literal meaning of going between-entre-and taking-prendre-ideas from others, where their disconnect prevents them from combining their ideas (Burt 2004; McGrath et al. 2006).

With such nuances in mind, we consider not only the network as a whole, but also consider the differentiation of the network into specific kinds or components (Burt and Schott 1985; Schott 2014). 
An entrepreneur is typically networking for advice in the private sphere, with spouse, parents, other family members, and also friends. Often an entrepreneur is also networking for advice in the public sphere comprising environments such as the workplace (with the work colleagues, boss, starter, and business mentor), the professions (with lawyer, accountant, bank, investor, researcher, and counselor), the market (with collaborators, competitors, suppliers, and customers), and internationally (with someone in another country and someone from abroad). The private and the public spheres comprising various environments have been distinguished in cluster analyses of networks around entrepreneurs in a survey (Cheraghi and Schøtt 2014; Schott 2014; Schott and Cheraghi 2012), which is also used here. The networking is extensive already in the earliest phases of entrepreneurship, and even the transnational networking is extensive in the intending phase, so that firms are not only born global, but are even conceived global (Cheraghi and Schøtt, forthcoming).

Entrepreneurs' networking varies among individuals and among countries. The tendency to network overall is typically larger in secular-rational culture than in traditional culture and wider where trust is universal than where distrust prevails. Networking in the private sphere is usually larger in traditional culture than in secular-rational culture, large in societies where those beyond family and close friends are distrusted, and small in societies where trust goes beyond family and close friends. Conversely, networking in the public sphere such as the professions, workplace, market and international environment tends to be larger in secular-rational culture than in traditional culture and larger in trusting societies than in distrusting societies (Schott and Cheraghi 2012; Cheraghi and Schøtt 2014). Entrepreneurs' networking in the public sphere, and especially transnational networking, benefits their exporting, but the benefit depends on culture as a moderating effect (Ashourizadeh and Schøtt, forthcoming). This benefit of social capital for exports is also enhanced by human capital as a moderating effect (Ashourizadeh et al. 2014).

\section{Hypotheses}

The review leads us to specify hypotheses. First hypotheses are specified about how innovation is embedded in advice networks around entrepreneurs.
The starting point is the well-known proposition that innovation benefits from overall networking, i.e., the more an entrepreneur networks for advice, the higher will expectedly be the entrepreneur's innovativeness:

Hypothesis 1 The size of a network has a positive effect on innovation.

This proposition is retested here as our starting point, but is also retested because our sample is so globally representative that it enables generalization to the world.

Networking for advice comprises networking the private sphere with family and friends and networking in the public sphere such as the workplace, professions, market, and internationally.

Networking in the private sphere is likely to provide resources in the way that the advice brings emotional support versus discouragement. Advice from the private sphere is expectedly not beneficial for innovation; indeed, when the entrepreneur spends much energy on advice from family and friends, the less the entrepreneur will invest and benefit from other networks and in this way the networking in the private sphere may even be detrimental. Therefore, we hypothesize:

Hypothesis 2 Private sphere networking has a negative effect on innovation.

An entrepreneur's networking in the public sphere may elicit other kinds of advice. The boss and coworkers in a workplace network may serve as sounding boards for the entrepreneur's ideas; they have experience and know-how as tacit knowledge that they can transmit to the entrepreneur and, in this way, likely be beneficial also for the entrepreneur's innovative work. Professionals are persons with expertise that is based on codified knowledge and therefore certified and trustworthy, and their advice is expectedly beneficial, also for the entrepreneur's innovative work. Networking in the market provides a channel for information about the needs of customers, possibilities for collaboration, and threats of competition, and such information is likely to be beneficial, also for the entrepreneur's innovative work. Discussing with persons abroad and persons from abroad is a source of ideas about opportunities that are different from the local opportunities and commonly known opportunities and therefore likely to be 
beneficial, also for the entrepreneur's innovative work. In short, we hypothesize that networking with advisors from the public sphere benefits innovation:

Hypothesis 3 Public sphere networking has a positive effect on innovation.

The individual behavior of networking and innovating is expectedly also affected by societal conditions. Entrepreneurs' action is increasingly contextualized as influenced by institutions in society: regulative institutions, normative institutions, and cultural-cognitive institutions. For example, a regulative arrangement such as a few procedures to start a business, a normative arrangement such as media praise of new business, and cultural-cognitive environments all influence people's entrepreneurial involvement such as becoming an entrepreneur (Urbano and Alvarez 2013). Institutions differ considerably among societies, creating much difference in peoples' pursuits of various kinds of entrepreneurship, e.g., opportunity- versus necessity-motivated entrepreneurship and autonomous entrepreneurship versus intrapreneurship (Levie et al. 2013).

Here we focus on how entrepreneurial endeavors are embedded in the national system of education for entrepreneurship. Here we shall consider the benefit to entrepreneurs' innovation from the quality of the national system of education for entrepreneurship in society. The quality of the national educational system directly enhances the entrepreneurs' human capital and makes them more creative and skillful. Indeed, entrepreneurs' formal education and their entrepreneurship training during schooling and also entrepreneurship training upon graduation all have positive effects upon their innovation, also when controlling for many other characteristics (Schott et al. 2012). In our analysis here, the entrepreneurs' education and other individual-level characteristics are not of focal interest and will be included merely as control variables. But the national system of education for entrepreneurship not only benefits human capital, but may also benefit social capital, namely as follows.

The quality of the national system of education for entrepreneurship builds human capital in the population, and specifically builds entrepreneurial competencies among those who give advice to the entrepreneurs, and thereby their advice gets added valuable. The quality of the national system thus raises the human capital of the advisors, and this becomes the social capital of the entrepreneur, which can benefit innovation. In yet other words, networking with advisors becomes especially beneficial when this is embedded in a national system of high quality. This benefit for innovation thus expectedly occurs by a combination of networking with the quality of the system. This effect is modeled as a moderating effect, a joint or combined or interaction effect of the quality of national system together with the entrepreneur's networking in the private and public spheres. We specify this as further hypotheses:

Hypothesis 4 Private sphere networking together with quality of the national educational system, in combination, adds benefit to innovation.

Hypothesis 5 Public sphere networking together with quality of the national educational system, in combination, adds benefit to innovation.

These hypotheses are tested below.

\section{Research design and data}

Entrepreneurial networking and innovation in the context of society can be investigated with two-level data on entrepreneurs nested in societies. Such hierarchical data are collected in the GEM by annual surveys in participating countries (Global Entrepreneurship Research Association 2013; Minniti 2011).

Countries have been sampled mainly by selfselection, typically when researchers in a country join GEM. GEM has surveyed networks in 61 societies: Algeria, Angola, Arab Emirates, Argentina, Australia, Bangladesh, Barbados, Bolivia, Bosnia and Herzegovina, Botswana, Brazil, China, Colombia, Costa Rica, Croatia, Czech Republic, Denmark, Ecuador, Egypt, El Salvador, Estonia, Ethiopia, Ghana, Greece, Guatemala, Hungary, Iran, Ireland, Israel, Jamaica, Jordan, Latvia, Lebanon, Malaysia, Mexico, Morocco, Namibia, Nigeria, Pakistan, Palestine, Peru, Poland, Portugal, Romania, Saudi Arabia, Singapore, South Africa, South Korea, Sweden, Syria, Taiwan, Thailand, Tonga, Trinidad and Tobago, Tunisia, Turkey, the US, Uruguay, Venezuela, Yemen, and Zambia. These 61 societies are fairly representative of the world, and adults are sampled fairly randomly, so the representativeness enables generalization to the world.

The Global Entrepreneurship Monitor (GEM) conducts a survey of adults reporting their entrepreneurial 
involvement and a survey for assessing the national framework (Reynolds et al. 2005). The individual level survey provides data on entrepreneurs' networking and innovation, and the national level survey provides data on the quality of the national educational system.

\subsection{Quality of the national system of education for entrepreneurship}

The GEM survey for assessing the national framework asked experts to rate several conditions, including the quality of the national system of education for entrepreneurship. The experts ascertained six statements about the quality,

In your country, teaching in primary and secondary education encourages creativity, self-sufficiency, and personal initiative.

In your country, teaching in primary and secondary education provides adequate instruction in market economic principles.

In your country, teaching in primary and secondary education provides adequate attention to entrepreneurship and new firm creation.

In your country, colleges and universities provide good and adequate preparation for starting up and growing new firms.

In your country, the level of business and management education provides good and adequate preparation for starting up and growing new firms.

In your country, the vocational, professional, and continuing education systems provide good and adequate preparation for starting up and growing new firms.

Each expert ascertained the truthfulness of each statement in terms of completely false, somewhat false, neither true nor false, somewhat true, and completely true, coded 1-5. The assessments were averaged across the experts, across the six statements, and across the years to yield a measure of the quality in the country, on the scale from 1 to 5 (Table 1). Averaging across the years, 2002-2012, measures a time period when many of the entrepreneurs and their advisors were formed in the educational system. The
Table 1 Countries with the highest quality and countries with the lowest quality of the national educational system

\begin{tabular}{ll}
\hline Singapore & 2.9 \\
Namibia & 2.9 \\
USA & 2.9 \\
Latvia & 2.8 \\
Arab Emirates & 2.7 \\
$\ldots$ & \\
Iran & 2.0 \\
Syria & 1.9 \\
Japan & 1.9 \\
Yemen & 1.6 \\
Egypt & 1.6 \\
\hline
\end{tabular}

differences across countries are far greater than fluctuations in the time series for each country. This measure of quality of the national education for entrepreneurship has reasonable validity, especially predictive validity in so far at it shows expected positive relationships with the rate of people's entry into entrepreneurship (Levie and Autio 2008).

Table 1 shows considerable variation among countries in their quality of the system of education for entrepreneurship. This measure is used to estimate how the quality of the national system is affecting innovation.

\subsection{Entrepreneurs' networking in public and private spheres}

In each country, a fairly randomly sample of adults, aged 18-64 years old, has been interviewed in the GEM population survey. Entrepreneurs were identified as those who own and manage a starting or operating enterprise. In the 61 countries, a sample of 56,611 entrepreneurs reported on their innovation and networking. The entrepreneurs were interviewed during 2009-2012. One of the causes, the quality of the national educational system, was measured around the same time and earlier, when many of the entrepreneurs and their advisors were formed by the educational system, so having this time lag in the measurements is appropriate for this causal mechanism.

Our hypothesis is that networking is a cause of innovation. Our data on the entrepreneurs are crosssectional, at the same time measuring networking and innovation. So we cannot be sure that networking is 
causally prior to innovation. Indeed, innovation may sometimes be a cause of networking, especially when innovation attracts others. But causality seems to be mostly in the direction from networking to innovation. First, very few of the potential advisors are persons who would be attracted by the innovativeness of the entrepreneur; they would be mainly other entrepreneurs and business people. Second, networking includes many who have been in the network for long, especially family and friends, and also the boss and co-workers. Third, the network seems altogether quite stable. Fourth, the personal network around an entrepreneur is formed before starting the firm (Schott 2013). For these reasons, networking is considered causally prior to innovation.

Each entrepreneur was asked about advice from various others (Bahn et al. 2011; Schott 2011; Kelley et al. 2011, p. 29). A first list of potential advisors was culled from the literature (e.g., Greve and Salaff 2003) and pretested in different countries (Coduras et al. 2010), a pretest that led us to drop a few potential advisors and add a few other potential advisors to our final list of 20 possible advisors (Global Entrepreneurship Research Association 2013). Each entrepreneur was asked:

Various people may give advice on your new business. Have you received advice from...Spouse? Parents? Other family? Friends?

Boss? Colleagues? A starter? A business mentor? An accountant? A lawyer? A bank? A potential investor? A researcher? A public counselor? A collaborating firm? A competing firm? A supplier? Customers? Someone abroad?

Someone from abroad?

This measurement of networking evidences predictive validity in terms of cultural and individual conditions explaining networking (Cheraghi and Schøtt 2014; Coduras et al. 2010: 39-42; Schott 2011) and in terms of networking predicting exporting and expectations for growth and returns (Bahn et al. 2011; Schott 2011). Networking in the private sphere is measured by the number of advisors among the four: spouse, parents, other family, and friends. Networking in the public sphere is measured by the number of advisors among the others. The classification of advisors into the two spheres is conceptual and is also empirical in the way
Table 2 Entrepreneurs, by size of each network (56,611 entrepreneurs)

\begin{tabular}{llll}
\hline & $\begin{array}{l}\text { Whole } \\
\text { network }\end{array}$ & $\begin{array}{l}\text { Private } \\
\text { sphere }\end{array}$ & $\begin{array}{l}\text { Public } \\
\text { sphere }\end{array}$ \\
\hline No advisor (\%) & 11 & 17 & 41 \\
1 Advisor (\%) & 15 & 24 & 15 \\
2 Advisors (\%) & 14 & 22 & 11 \\
3 Advisors (\%) & 13 & 20 & 8 \\
4 Advisors (\%) & 11 & 16 & 6 \\
5 Advisors (\%) & 8 & & 5 \\
6 Advisors (\%) & 7 & & 4 \\
7 Advisors (\%) & 5 & & 3 \\
8 Advisors (\%) & 4 & & 2 \\
9 Advisors (\%) & 3 & & 2 \\
10 Advisors (\%) & 3 & & 1 \\
11 Advisors (\%) & 2 & & 1 \\
12 Advisors (\%) & 1 & & .2 \\
13 Advisors (\%) & 1 & & .2 \\
14 Advisors (\%) & 1 & & .1 \\
15 Advisors (\%) & 1 & & \\
16 Advisors (\%) & .4 & & \\
17 Advisors (\%) & .3 & & \\
18 Advisors (\%) & .2 & & \\
19 Advisors (\%) & .1 & & \\
20 Advisors (\%) & .2 & & \\
Total (\%) & 100 & & \\
Mean number of advisors & 4.24 & & \\
SD & 3.66 & & \\
Coefficient of variation & .86 & & \\
\hline
\end{tabular}

that a cluster analysis of the 20 advisors distinguishes the four-spouse, parents, other family, and friendsfrom the others. Entrepreneurs differ in their networking in each sphere (Table 2).

Some entrepreneurs have a small network overall, whereas others have a large network. Some entrepreneurs have a small private sphere network, but most network significantly in the private sphere. Many entrepreneurs network extremely little in the public sphere, but many others have several advisors in the public sphere.

\subsection{Innovation in the entrepreneur's enterprises}

Innovation is here broadly conceived to encompass both process innovation as newness of the technology used in producing goods or services and product 
Table 3 Entrepreneurs' innovation along three dimensions (56,611 entrepreneurs)

\begin{tabular}{lccc}
\hline & $\begin{array}{l}\text { Newness of } \\
\text { technology } \\
(\%)\end{array}$ & $\begin{array}{l}\text { Competitiveness } \\
(\%)\end{array}$ & $\begin{array}{l}\text { Newness to } \\
\text { customers } \\
(\%)\end{array}$ \\
\hline High innovation & 12 & 7 & 17 \\
$\begin{array}{l}\text { Medium } \\
\text { innovation }\end{array}$ & 18 & 31 & 28 \\
Low innovation & 70 & 62 & 55 \\
Total & 100 & 100 & 100 \\
\hline
\end{tabular}

innovation as newness of the product to customers, and also competitiveness or scarceness of competitors on the market. Accordingly, the GEM survey asks the entrepreneurs,

Have the technologies or procedures required for this product or service been available for less than a year, or between 1 to 5 years, or longer than 5 years?

Do all, some, or none of your potential customers consider this product or service new and unfamiliar?

Right now are there many, few, or no other businesses offering the same products or services to your potential customers?

The response to each question is given on a 3-point scale, interpretable as low, medium, and high innovation. Entrepreneurs differ from each other on each dimension (Table 3).

Table 3 shows that, on each dimension, entrepreneurs differ in the way that most entrepreneurs are low on innovation and only a few are highly innovative. There is a tendency that if innovation is high on one dimension then it is also high on the other dimensions, and vice versa. Thus, the three dimensions are positively correlated (when each dimension is coded 1-3) and can be averaged to an index of innovation. Innovation is skewed, most entrepreneurs are low on innovation, and few entrepreneurs have high innovation. This index of innovation seems reasonably valid; in particular, its criterion validity seems good, as indicated by an analysis showing a positive effect of the network of business relations around firms on their innovation (reported toward the end of this article), as measured by the index. This index of innovation is used for estimating effects on innovation. 4.4 Controlling for attributes of entrepreneurs
and firms

The entrepreneurs reported on their networking and innovation, as detailed above, and on other characteristics of themselves and their firms (the questionnaire is published; GERA, 2013). These will serve as control variables, with the following measurements:

Gender

Age of entrepreneur

Education

Household size

Self-efficacy

Opportunity perception

Risk-willingness

Motivation

Phase

Sole proprietor

Firm owners

Firm age

Firm size

\section{Dichotomy coded 1 for male and 0 for female} Logarithm of the number of years of age

Level of education, standardized within each national sample

Logarithm of the number of persons in the household Dichotomy coded 1 for self-efficacious and 0 for not

Dichotomy coded 1 if recognizing opportunity and 0 if not

Dichotomy coded 1 if not fearing and 0 if fearing failure

Categorical: Opportunity, necessity, both, has a job but seeks opportunity, other Dichotomy coded 0 if starting phase and 1 if operating phase

Dichotomy coded 0 if joint ownership and 1 if sole ownership

Logarithm of the number of owners

Logarithm of the number of years plus one

Logarithm of the number of employees plus the ownermanager

The above variables are used for estimating metric coefficients, and their standardized variables are used for estimating standardized coefficients.

Effects on an individual outcome (innovation) from both personal characteristics (networking and controls) and context (quality of the national educational 
system) might be examined by a multiple linear regression, but this is not the most appropriate because our data are about individual (with a huge $N$ of cases) and country (with 61 cases) and because our individuals are sampled within a sample of countries, with some similarity of behavior within each country, an autocorrelation of residuals. More appropriate is a hierarchical mixed linear model (Raudenbush and Bryk 2002). This model is hierarchical by handling data that are hierarchical, entrepreneurs within countries. The model is linear as a way of modeling association between numerical variables. The model has 'fixed' coefficients for effects of the variables of interest and also the controls, and has 'random' coefficients for countries ('random' refers to the sample of countries), so the model is called mixed by having both fixed and random effects. The model also controls for the autocorrelated behavior within each country. An effect is estimated by a coefficient and tested with a probability value that for a nationallevel variable takes into account that this is measured only on 61 cases. Such hierarchical linear mixed modeling is increasingly used, also in regional studies of several regions and in research on entrepreneurs in a social context (e.g., Autio and Acs 2010; Cheraghi and Schøtt 2014; Schott and Cheraghi 2012; Kwon and Arenius 2010).

\section{Innovation embedded in networks around entrepreneurs}

Our starting point is the proposition that innovation is positively affected by the size of the network around the entrepreneur, stated as Hypothesis 1. In the hierarchical linear model, as described above, each effect is estimated by a coefficient (Table 4) (the coefficients for the 61 countries are omitted from the table).

Table 4 shows that size of the network around entrepreneurs positively affects innovation, reconfirming the proposition. The more an entrepreneur networks, overall, the more innovative the entrepreneur is likely to be, also when controlling for many other conditions.

The quality of the national system of education for entrepreneurship has no significant effect directly upon innovation, other things controlled for. That quality of the system is not directly affecting
Table 4 Entrepreneurs' innovation affected by size of their whole network

\begin{tabular}{|c|c|c|c|}
\hline & $\begin{array}{l}\text { Metric } \\
\text { coefficient }\end{array}$ & $\begin{array}{l}\text { Standardized } \\
\text { coefficient }\end{array}$ & $p$ value \\
\hline Size of whole network & .01 & .04 & $<.0001$ \\
\hline Gender being male & -.02 & -.02 & $<.0001$ \\
\hline Age of entrepreneur & -.04 & -.02 & $<.0001$ \\
\hline $\begin{array}{l}\text { Education of } \\
\text { entrepreneur }\end{array}$ & .01 & .03 & $<.0001$ \\
\hline Household size & -.02 & -.04 & .0001 \\
\hline Self-efficacy & .005 & .004 & .41 \\
\hline Opportunity-perception & .01 & .01 & .04 \\
\hline Risk-willingness & .01 & .01 & .01 \\
\hline Motivation: necessity & -.06 & -.06 & $<.0001$ \\
\hline $\begin{array}{l}\text { Motivation: both } \\
\text { opportunity and need }\end{array}$ & -.03 & -.02 & $<.0001$ \\
\hline $\begin{array}{l}\text { Motivation: has job, } \\
\text { seek opportunity }\end{array}$ & .03 & .02 & .0003 \\
\hline Motivation: other reason & .004 & .002 & .74 \\
\hline Phase operating & -.08 & -.08 & $<.0001$ \\
\hline Sole proprietorship & -.01 & -.01 & .12 \\
\hline Firm owners & .03 & .03 & $<.0001$ \\
\hline Firm age & -.06 & -.14 & $<.0001$ \\
\hline Firm size & .03 & .05 & $<.0001$ \\
\hline $\begin{array}{l}\text { National system of } \\
\text { education }\end{array}$ & -.04 & -.02 & .60 \\
\hline Intercept & 1.74 & .04 & \\
\hline $\begin{array}{l}\text { Country, a coefficient } \\
\text { for each country }\end{array}$ & $\begin{array}{l}\text { Not listed } \\
\text { here }\end{array}$ & & \\
\hline
\end{tabular}

Based on 61 countries with 44,095 entrepreneurs. Motivation by opportunity is the reference category

innovation may be unexpected but is understandable; the quality of the system of education increases the education of the entrepreneurs, which is seen to have a positive effect on innovation, so the quality of the system thereby indirectly promotes innovation.

Refining the proposition that innovation is embedded in networking, we had hypothesized that innovation benefits from public sphere networking but suffers from private sphere networking, as our Hypothesis 2 and Hypothesis 3. These hypotheses are tested by including size of the public sphere network and size of the private sphere network in the model (instead of size of the whole network, with the same controls as in Table 4) and Table 5.

Table 5 shows that innovation is reduced by networking in the private sphere, supporting Hypothesis 2, albeit this negative effect is small. Innovation 
Table 5 Entrepreneurs' innovation affected by public sphere network and private sphere network

\begin{tabular}{llll}
\hline & $\begin{array}{l}\text { Metric } \\
\text { coefficient }\end{array}$ & $\begin{array}{l}\text { Standardized } \\
\text { coefficient }\end{array}$ & $p$ value \\
\hline $\begin{array}{l}\text { Networking } \\
\text { in private } \\
\text { sphere }\end{array}$ & -.01 & -.03 & $<.0001$ one-sided \\
$\begin{array}{l}\text { Networking } \\
\text { in public } \\
\text { sphere }\end{array}$ & .01 & .06 & $<.0001$ one-sided \\
$\begin{array}{l}\text { Etc.. as in } \\
\text { Table } 4\end{array}$ & & & \\
\hline
\end{tabular}

Based on 61 countries with 44,095 entrepreneurs

benefits from networking in the public sphere. The benefit is of notable magnitude, as indicated by the standardized coefficient. This supports Hypothesis 3. The benefit from public sphere networking is greater than the detriment suffered from private sphere networking.

A further refinement is to consider networking in the public sphere to comprise networking in several environments. We can conceptually and empirically distinguish among four components of the public sphere network, namely networks in the workplace, professions, market and international environment as described earlier. We would expect each of these specific networks to benefit innovation. The effect of networking in each environment is estimated by the coefficients in a model. Networking in the professions and networking internationally both have notable benefits for innovation (with standardized coefficients of .05 and .06 , respectively).

In short, innovation is embedded in the network around entrepreneurs in the way that while innovation is promoted by overall networking, innovation is reduced by private sphere networking and benefitting from networking in the public sphere, especially in the professions and internationally.

\section{Embeddedness in the national system of education for entrepreneurship}

We had hypothesized that networking in the private sphere together with quality of the national system of education for entrepreneurship, in combination, adds benefit to innovation, Hypothesis 4. We had also hypothesized that, likewise, networking in the public sphere together with the quality of the national system of education for entrepreneurship, in combination, adds benefit to innovation, Hypothesis 5. These two hypotheses are tested by including interaction terms, the product of the national system with each kind of network (Table 6).

Private sphere networking in combination with quality of the national system has a positive effect on innovation. This supports Hypothesis 4.

Likewise, public sphere networking in combination with the quality of the national system also has a positive effect on innovation. This supports Hypothesis 5.

The magnitude of the two moderating effects can be ascertained by comparing the network effect at the low end to the network effect at the high end of the spectrum of the quality of the national educational systems. At the low end, the quality is 1.6 (Table 1), so with the metric coefficients in Table 6 , the effects of the public sphere network and the private sphere network are estimated as:

-.01 Public -.06 Private $+.01 * 1.6$ Public

$+.02 * 1.6$ Private or

.006 Public Sphere Network

- .028 Private Sphere Network.

So in a place with low quality of the educational system, the benefit of public sphere networking may well be outweighed by the detriment of private sphere networking. In contrast, at the high end, the quality is 2.9 (Table 1), so the network effects are estimated as:

-.01 Public -.06 Private $+.01 * 2.9$ Public

$+.02 * 2.9$ Private or

.019 Public Sphere Network

- .002 Private Sphere Network.

So in a place with high quality of the educational system, the benefit of any public sphere networking is far greater than any detriment of private sphere networking. In short, the quality of the national educational system can considerably add to the benefits of networking.

\section{Conclusions, relevance and future research}

The analyses have examined how innovation is embedded in networks around entrepreneurs and 
Table 6 Entrepreneurs' innovation affected by the quality of the national system in combination with the public sphere network and private sphere network

\begin{tabular}{|c|c|c|c|}
\hline & Metric coefficient & Standardized coefficient & $p$ value \\
\hline Public sphere network & -.01 & .06 & \\
\hline Private sphere network & -.06 & -.03 & \\
\hline National educational system & -.10 & -.02 & \\
\hline Public network $*$ national system & .01 & .01 & .01 one-sided \\
\hline Private network $*$ national system & .02 & .01 & .006 one-sided \\
\hline Etc. as in Table 4 & & & \\
\hline
\end{tabular}

Based on 61 countries with 44,095 entrepreneurs

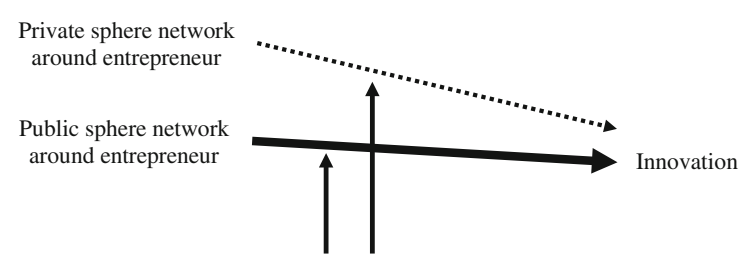

Quality of national system of education for entrepreneurship

Fig. 2 Estimated effects

embedded in society. The proposition that innovation benefits from overall networking was reconfirmed but was also refined by distinguishing between networking in the private sphere and networking in the public sphere. Networking in the private sphere has a negative, albeit small, effect, whereas substantial benefits for innovation are carried by networking in the public sphere, especially in the professions and internationally. The negative effect from private sphere networking is shown by the dotted arrow in Fig. 2, and the positive effect from public sphere networking is shown by the solid arrow, fatter because this effect is stronger.

Entrepreneurial behavior was contextualized by analyzing embeddedness in society, specifically in the national system of education for entrepreneurship.

The quality of the national system adds value to networking; that is, quality increases the benefit to innovation from networking in the private and public spheres. These two added values are shown by the two solid arrows from quality of the national system.

In short, entrepreneurs' innovation is shaped by their individual characteristics, specifically their networking, and by the context of their society, specifically the quality of the national system of education for entrepreneurship.

Theoretically, the study contributes to our understanding of the dynamics of entrepreneurship in society by demonstrating how entrepreneurs' behavior is not atomistic but embedded in networks and in institutions in society.

\subsection{Relevance for policy for networking and innovation}

Policy-making can utilize two major findings from our study. First, policy-making may use the finding that innovation can be enhanced by promoting the quality of the national system of education for entrepreneurship, especially in combination with entrepreneurial networking. Second, that innovation can be enhanced by promoting networking, especially international and professional networking. This second utility of the study is a specification of the recommendation now being promulgated by the OECD that efficient
Fig. 3 Hypothesized embeddedness of innovation in networks around entrepreneurs and enterprises

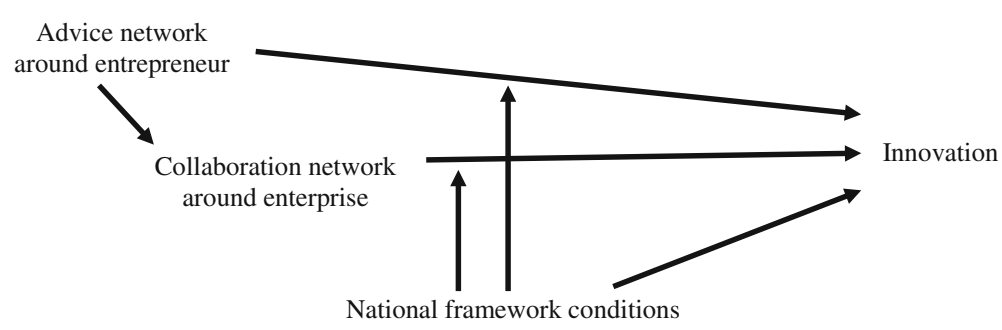


knowledge flows should be facilitated and development of networks should be fostered that enable the creation, circulation, and diffusion of knowledge (OECD 2010). This advocacy of network linkages for innovation is also promulgated in The Global Innovation Index 2012: Stronger Innovation Linkages for Economic Growth (Dutta 2012).

\subsection{Future research: embeddedness in collaboration networks around enterprises}

What is the channel through which the personal network around an entrepreneur affects innovation in the enterprise of the entrepreneur? One important channel, we submit, is the business network around the enterprise. The business network includes collaboration with others (Grabher 1993). An enterprise may collaborate with other organizations and firms about ongoing operations such as production, supplies, and sales, about novel operations, and also about organizing the enterprise (Oliver 2009). This business network around the enterprise, we hypothesize, is embedded in the personal advice network around the entrepreneur and promotes innovation of the enterprise. The hypothesized dynamic is illustrated in Fig. 3.

The business network around the entrepreneur's enterprise has been surveyed in GEM in 2012. Each entrepreneur was asked several questions about collaboration of the enterprise with other organizations and firms about its operations. The collaboration of the enterprise can then be indicated by the average of the relations and analyzed together with the entrepreneurs' personal network and with the innovation in the enterprise.

The dynamic is indicated, as a first indication, by the correlations, expected to be positive. The collaboration network correlates .32 with the personal network and correlates .14 with innovation. These positive and substantial correlations indicate that this research will be fruitful for our understanding of networks around entrepreneurs and their enterprises and consequences of networking.

Acknowledgments We are grateful to the Danish Industry Foundation, Industriens Fond, for financial support and to colleagues in the GEM consortium for surveys; the responsibility for analyses and interpretations rests with the authors.
Open Access This article is distributed under the terms of the Creative Commons Attribution License which permits any use, distribution, and reproduction in any medium, provided the original author(s) and the source are credited.

\section{References}

Ashourizadeh, S., \& Schøtt, T. (forthcoming). Exporting embedded in culture and transnational networks around entrepreneurs. International Journal of Business and Globalization.

Ashourizadeh, S., Rezaei, S., Schøtt, T., \& Vang, J. (2014). Entrepreneurs' human and social capital: Direct and reinforcing benefits for export. International Journal of Entrepreneurship and Small Business, 21(2), 246-267.

Autio, E., \& Acs, Z. (2010). Intellectual property protection and the formation of entrepreneurial growth aspirations. Strategic Entrepreneurship Journal, 4, 234-251.

Bahn, S., Greco, S. M., Farsi, J. Y., Rastrigina, O., \& Schøtt, T. (2011). Entrepreneurs' expected returns affected by their networks: A cross-national study using Global Entrepreneurship Monitor data. Asia Pacific Journal of Innovation and Entrepreneurship, 5(2), 75-94.

Baptista, R., \& Swann, P. (1998). Do firms in clusters innovate more? Research Policy, 27, 525-540.

Belussi, F., Sammarra, A., \& Sedita, S. R. (2010). Learning at the boundaries in an 'Open Regional Innovation System': A focus on firms' innovation strategies in the Emilia Romagna life science industry. Research Policy, 39, 710-721.

Burt, R. S. (2004). Structural holes and good ideas. American Journal of Sociology, 110(2), 349-399.

Burt, R. S., \& Schott, T. (1985). Relation contents in multiple networks. Social Science Research, 14, 287-308.

Carlsson, B., Braunerhjelm, P., McKelvey, M., Olofsson, C., Persson, L., \& Ylinenpää, Y. (2013). The evolving domain of entrepreneurship research. Small Business Economics, 41, 913-930.

Cheraghi, M., \& Schøtt, T. (2014). Size, diversity and components in the network around an entrepreneur: Shaped by culture and shaping embeddedness of firm relations. In F. Polat, F. Can, \& T. Özyer (Eds.), State of the art applications of social network analysis. Heidelberg: Springer.

Cheraghi, M., \& Schøtt, T. (forthcoming). Conceived global: Entrepreneurs' transnational networking, across phases and embedded in culture. International Journal of Business and Globalization.

Coduras, A., Levie, J. D., Kelley, D., Sæmundsson, R. J., \& Schøtt, T. (2010). A global perspective on entrepreneurship education and training. GERA/GEM.

Coleman, J. S. (1990). Foundations of social theory. Cambridge: Harvard University Press.

Dahl, M. S., \& Pedersen, C. Ø. R. (2005). Social networks in the $\mathrm{R} \& \mathrm{D}$ process: The case of the wireless communication industry around Aalborg, Denmark. Journal of Engineering and Technological Management, 22, 75-92.

Davidsson, P., \& Honig, B. (2003). The role of social and human capital among nascent entrepreneurs. Journal of Business Venturing, 18, 301-331. 
Dutta, S. (ed.) (2012). The Global Innovation Index 2012: Stronger innovation linkages for economic growth. http:// www.globalinnovationindex.org/gii/.

Edquist, C., Eriksson, M.-L., \& Sjögren, H. (2000). Collaboration in product innovation in the East Gothia regional system of innovation. Enterprise and Innovation Management Studies, 1(1), 37-56.

Global Entrepreneurship Research Association. (2013). Global Entrepreneurship Monitor. http://www.gemconsortium.org.

Grabher, G. (1993). The embedded firm. On the socioeconomics of interfirm relations. London: Routledge.

Granovetter, M. (1985). Economic action and social structure: The problem of embeddedness. American Journal of Sociology, 91(3), 481-510.

Greene, P. G., \& Rice, M. P. (2007). Entrepreneurship education. Cheltenham: Edward Elgar.

Greve, A., \& Salaff, J. W. (2003). Social networks and entrepreneurship. Entrepreneurship Theory and Practice, 28(1), $1-22$.

Gronum, S., Verreynme, M.-L., \& Kastelle, T. (2012). The role of networks in small and medium-sized enterprise innovation and performance. Journal of Small Business Management, 50, 257-282.

Hofstede, G., Hofstede, G. J., \& Minkov, M. (2010). Cultures and organizations. New York: McGraw-Hill.

Kelley, D., Brush, C. G., Greene, P. G., \& Litovsky, Y. (2011). Global Entrepreneurship Monitor 2010 women's report. Babson Park: Babson College.

Kolvereid, L., Isaksen, E. J., \& Ottósson, H. (2009). Advice to new business founders and subsequent venture performance. In C. G. Brush, L. Kolvereid, L. Ø. Widding, \& R. Sørheim (Eds.), The life cycle of new ventures: Emergence, newness and growth (pp. 202-217). Cheltenham: Edward Elgar.

Kwon, S.-W., \& Arenius, P. (2010). Nations of entrepreneurs: A social capital perspective. Journal of Business Venturing, 25, 315-330.

Levie, J. D., \& Autio, E. (2008). A theoretical grounding and test of the GEM model. Small Business Economics, 31(3), 235-263.

Levie, J., Autio, E., Acs, Z., \& Hart, M. (2013). Global entrepreneurship and institutions: An introduction. Small Business Economics. doi:10.1007/s11187-013-9516-6.

Lundvall, B.- $\AA$. (1992). National systems of innovation: Toward a theory of innovation and interactive learning. London: Francis Pinter.

McGrath, C. A., Pate, L. E., Gray, E. R., \& Vance, C. E. (2006). Getting wired for innovation: An analysis of the advice networks of software entrepreneurs. International Journal of Organizational Analysis, 14(4), 317-330.

Merton, R. K. (1938). Science, technology and society in seventeenth century England. Burges: Sainte Catherine Press.

Minniti, M. (Ed.). (2011). The dynamics of entrepreneurship: Evidence from the Global Entrepreneurship Monitor. New York: Oxford University Press.

Moulaert, F., \& Nussbaumer, J. (2005). The social region: Beyond the territorial dynamics of the learning economy. European Urban and Regional Studies, 12, 45-64.

OECD. (2010). The OECD innovation strategy: Getting a head start on tomorrow. Paris: OECD.
Oliver, A. L. (2009). Networks for learning and knowledge creation in biotechnology. Cambridge: Cambridge University Press.

Pittaway, L., Robertson, M., Munir, K., Denyer, D., \& Neely, A. (2004). Networking and innovation: A systematic review of the evidence. International Journal of Management Reviews, 5/6(3\&4), 137-168.

Powell, W. W., Koput, K. W., \& Smith-Doerr, L. (1996). Interorganizational collaboration and the locus of innovation: Networks of learning in biotechnology. Administrative Science Quarterly, 41(1), 116-145.

Raudenbush, S. W., \& Bryk, A. S. (2002). Hierarchical linear models: Applications and data analysis methods (2nd ed.). Newbury Park: Sage.

Reynolds, P., Bosma, N. S., Autio, E., Hunt, S., De Bono, N., Servais, I., et al. (2005). Global Entrepreneurship Monitor: Data collection design and implementation 1998-2003. Small Business Economics, 24(3), 205-231.

Sarasvathy, S. D. (2008). Effectuation: Elements of entrepreneurial expertise. Northampton: Edward Elgar.

Schott, T. (2009). Education, training and networking for entrepreneurship in Denmark 2008: Studied via Global Entrepreneurship Monitor. Kolding: University of Southern Denmark.

Schott, T. (2011). Training and network organization in entrepreneurship in Denmark 2010: Studied via Global Entrepreneurship Monitor. Kolding: University of Southern Denmark.

Schott, T. (2013). Evolution of embeddedness of a firm's business network in its owner-manager's personal network. In XXVIII Sunbelt Conference, Hamburg, May.

Schott, T. (2014). Components in the network around an actor. In R. Alhajj \& J. Rokne (Eds.), Encyclopedia of social network analysis and mining. Heidelberg: Springer.

Schott, T., \& Cheraghi, M. (2012). Entrepreneurs' networks: Size, diversity and composition shaped by cultures of rationality and trust. In Proceedings of the 2012 IEEE/ACM international conference on advances in social network analysis and mining (pp. 220-226) August 2012, Istanbul. Los Alamitos, California: IEEE Computer Society.

Schott, T., Hovne, A. S., \& Hovne, B. S. (2012). Entrepreneurs' innovation promoted by their education and training and by national policy and culture: A global study. In M. Muffatto \& P. Giacon (Eds.), Entrepreneurial strategies and policies for economic growth (pp. 81-94). Padova: LibriaUniversitaria.it.

Shane, S. A. (1992). Why do some societies invent more than others? Journal of Business Venturing, 7(1), 29-46.

Shane, S. A. (1993). Cultural influences on national rates of innovation. Journal of Business Venturing, 8(1), 59-73.

Shane, S. A. (2003). A general theory of entrepreneurship: The individual-opportunity Nexus. Northampton: Edward Elgar.

Urbano, D., \& Alvarez, C. (2013). Institutional dimensions and entrepreneurial activity: An international study. Small Business Economics. doi:10.1007/s11187-013-9523-7.

Weber, M. (1920). The protestant ethic and the spirit of capitalism. Los Angeles: Roxbury Publishing.

Zhao, L., \& Aram, J. (1995). Networking and growth of young technology-intensive ventures in China. Journal of Business Venturing, 10, 349-370. 